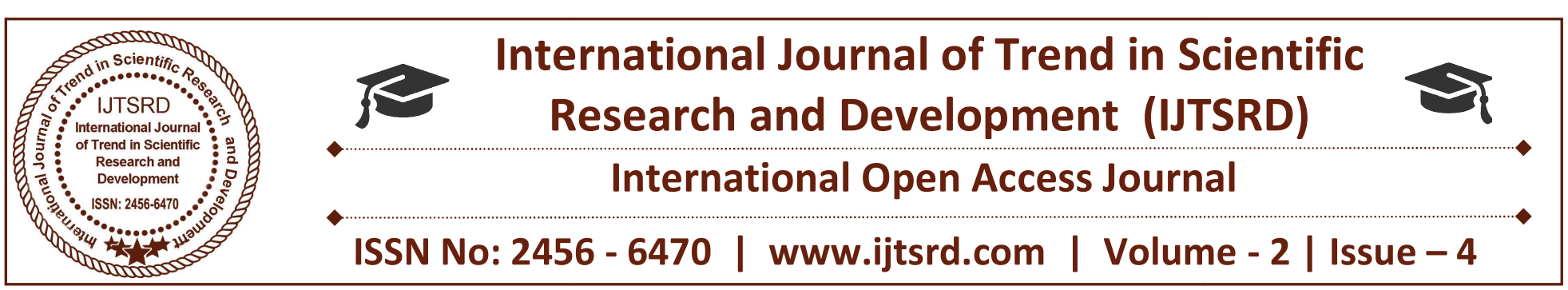

\title{
Infrastructure Facility and Entrepreneurship Development Among Women - A Case Study of Sonitpur District of Assam
}

\author{
Mala Mahanta ${ }^{1}$, Dr. Parbin Sultana ${ }^{2}$ \\ ${ }^{1}$ Research Scholar, ${ }^{2}$ Associate Professor, \\ University of Science and Technology, Meghalaya, India
}

\begin{abstract}
Entrepreneurship is a creative process in which predetermined goals are achieved using various resources in a systematic and coordinated manner to perform activities in an efficient way. Entrepreneurship is a driving force of the economy. Entrepreneurship provides a main solution to the problems of unemployment and proper utilization of all resources (human and non-human). It plays an important role in improving the standard of living of the people. There is a positive relationship between infrastructure and entrepreneurship. Infrastructure can help to enhance connectivity and linkages that facilitate recognition of entrepreneurial opportunities and the ability of entrepreneurs to actualize those opportunities. Generally entrepreneurial infrastructure includes the facilities and services present within a given geographic area which encourage the birth of new ventures and the growth and development of small and medium sized enterprises. Shed allotment, power supply, road, railways, industrial parks, well funded and structured programmes which provides funding, market support network and business advisory service are part of a robust entrepreneurial infrastructure. Entrepreneurial infrastructure helps to develop strong tradition of self-reliance and entrepreneurship which is critical in starting up new enterprises that create employment and deliver superior services and products. For women, entrepreneurship is essentially a journey out of poverty and towards equality and equity. Women entrepreneurs are increasingly being considered to be an important catalyst for economic development. According to Harbison. F (1965), ''any women or group of women which innovates, initiates or adopts an economic activity may be called women

entrepreneur'. Not only do they contribute to employment creation and economic growth through their increasing numbers, but they also make a contribution to the diversity of entrepreneurship in the economic development. This paper explores the availability of infrastructural facilities for entrepreneurship development among women in Sonitpur district of Assam

Keywords: Infrastructure, Entrepreneurship, Connectivity, Structure, Opportunities

\section{INTRODUCTION}

Entrepreneurship is a creative process in which predetermined goals are achieved using various resources in a systematic and coordinated manner to perform activities in efficient way. Entrepreneurship provides a main solution to the problems of unemployment and proper utilization of all resources (human and nonhuman). It plays an important role in improving the standard of living of the people. The term 'entrepreneur' is of a relatively recent origin and evolving one also. It is mainly associated with economic and industrial development of an economy. The word 'entrepreneur' has been taken from the French language enterprendre where it originated literally means "between-taker" and "go-between" i.e. "to undertake" and meant to designate an organizer of musical or other entertainments. Richard Cantillon, an Irishman living in France, was the first who introduced the term 'entrepreneur' and his unique risk-bearing function in economics in the early $18^{\text {th }}$ century. He defined "entrepreneur as an agent who buys factors of production at certain prices in order to combine them into a product with a view to selling it
\end{abstract}


at prices in future'. J.B.Say viewed entrepreneur as the coordinator of the system, acting as an intermediary between all of the other agents of production and taking on the uncertainty and risk. According to Say, the profit that entrepreneur gained was the reward for the risk undertaken. Significant qualification is essential for successful entrepreneurship. To be a successful entrepreneur, the individual must have self-confidence, self motivation, understand business management, attending training programme, know about market and market related risk, maintain balance between home and business, knowledge about government schemes and monetary assistance.

For women, entrepreneurship is a journey out of poverty and towards equality. Women entrepreneurs are increasingly being considered to be an important catalyst for economic development. Not only do they contribute to employment creation and economic growth through their increasing numbers, but they also make a contribution to the diversity of entrepreneurship in the economic development. Moreover, their journey shows the transformation of nations from being under-developed or developing to developed ones. This paper explores the infrastructural facility available in the study area and its impact on development of women entrepreneur.

\section{Objectives:}

1. To find out the socio-economic background of women entrepreneurs in Sonitpur district of Assam

2. To find out infrastructural facilities available for entrepreneurship development

3. To offer suggestions for development of women entrepreneurs

\section{Significance of the study:}

Sonitpur district of Assam is purposively selected as this district has the potential to probe into the entrepreneurial behaviour of women. Basically Sonitpur district is an agricultural based district. The literacy rate of women in Sonitpur is 60.73 (2011) percent. With the increase of population, urbanisation, and Self Help Groups (SHGs) under the Swarna Jayanti Gram Swarozgar Yojana (1999), the market condition of small enterprises is gradually increasing. Moreover, Sonitpur is a tourist destination place and also due to existence of multicultural ethnic groups, there is a possibility of women entrepreneurship in different fields such as handloom, handicraft, cafe, traditional food items (Assamese cuisine), restaurants/dhaba, boutique, beauty parlour, financial consultancy/agents, hobby classes, etc. The number of women entrepreneurs has been increasing gradually. This study attempts to sketch the availability of infrastructure facilities and entrepreneurship development among women which helps in transforming the economy and also the standard of life of women in the study area.

\section{Methodology:}

Descriptive survey method is used to examine the existing condition of women entrepreneurship in Sonitpur district of Assam.

\section{Statistical tool:}

The collected data are analysed by applying simple statistical techniques like percentage, tables, graphs etc. to find out the demographic profile of women entrepreneurs and to draw inferences.

\section{Population of the study}

The population of the study are all registered and unregistered women entrepreneurs in Sonitpur district of Assam.

\subsection{Sources of data for the study}

The study is based on both primary and secondary data. Primary data is collected through structured questionnaires. Sources of secondary data are collected from web, news paper, journals, magazines, etc.

\section{Sample size is 430Socio-economic profile of women entrepreneur in Sonitpur}

The demographic and personal features determine how various entrepreneurial activities among women lead to their entrepreneurial development in Sonitpur district. These characteristics are a composition of variables like age, caste, occupation, family size and structure, marital status, educational standards, involvement and work experience, family income from entrepreneurial and allied activities. These are discussed below. 
International Journal of Trend in Scientific Research and Development (IJTSRD) ISSN: 2456-6470

\section{Socio-economic profile of the women entrepreneur in study area \\ Table - 1}

\begin{tabular}{|c|c|c|c|}
\hline Variables & Category & $\begin{array}{l}\text { Number of } \\
\text { respondents }\end{array}$ & Percentage $(\%)$ \\
\hline \multirow[t]{3}{*}{ Age } & $20-30$ & 76 & 17.67 \\
\hline & $30-40$ & 190 & 44.19 \\
\hline & Above 40 & 164 & 38.14 \\
\hline \multirow[t]{4}{*}{ Educational qualification } & $\begin{array}{l}\text { Below and equal to } \\
10^{\text {th }} \text { standard }\end{array}$ & 58 & 13.49 \\
\hline & $12^{\text {th }}$ standard & 186 & 43.25 \\
\hline & B.A. & 169 & 39.30 \\
\hline & M.A. & 17 & 3.95 \\
\hline \multirow[t]{3}{*}{ Marital Status } & Married & 219 & 50.93 \\
\hline & Unmarried & 152 & 35.35 \\
\hline & Widow & 59 & 13.72 \\
\hline \multirow{3}{*}{ Family structure } & Nuclear $5 \mathrm{Clen}$ & 189 & 43.95 \\
\hline & Joint family & 241 & 56.05 \\
\hline & 80.20 & QR & \\
\hline \multirow{3}{*}{$\begin{array}{l}\text { Number of dependent members } \\
\text { in family }\end{array}$} & 30 & 143 & 33.25 \\
\hline & & 167 & 38.84 \\
\hline & Above 6 & 120 & 27.90 \\
\hline \multirow{4}{*}{ Monthly income } & Up to Rs. 10,000 & 139 & 32.32 \\
\hline & Rs. $10,000-30,000$ & 171 & 39.77 \\
\hline & Rs.30,000-50,000 $\mathrm{S}$ & $90=$ & 20.93 \\
\hline & Above Rs. 50,000 & 30 & 6.98 \\
\hline \multirow[t]{4}{*}{ Location of enterprise } & Home based & काजिए 146 & 33.95 \\
\hline & $\begin{array}{l}\text { Rented outside elopr } \\
\text { Premises }\end{array}$ & nent $90 \quad$ & 20.93 \\
\hline & $\begin{array}{l}\text { Owned outside } \\
\text { premises }\end{array} 2456=$ & 105 & 24.42 \\
\hline & Road side & 89 & 20.70 \\
\hline \multirow[t]{3}{*}{ Sources of finance } & Self & 190 & 44.19 \\
\hline & Relatives, friends & +166 & 38.60 \\
\hline & Financial institutions & 74 & 17.21 \\
\hline \multirow[t]{3}{*}{ Size of enterprises } & Small & -430 & 100 \\
\hline & Medium & 00 & 0 \\
\hline & Big & 00 & 0 \\
\hline \multirow{2}{*}{ Legal structure of enterprises } & Registered & 149 & 34.65 \\
\hline & Non-registered & 281 & 65.35 \\
\hline \multirow[t]{4}{*}{ Origin of business } & Self-created & 188 & 43.72 \\
\hline & Bought & 85 & 19.77 \\
\hline & Inherited & 122 & 28.37 \\
\hline & Proxy owner & 35 & 8.14 \\
\hline \multirow{4}{*}{$\begin{array}{l}\text { Community of women } \\
\text { entrepreneur }\end{array}$} & $\mathrm{SC}$ & 142 & 33.02 \\
\hline & ST & 102 & 23.72 \\
\hline & $\mathrm{OBC}$ & 84 & 19.53 \\
\hline & General & 102 & 23.72 \\
\hline
\end{tabular}


Table - 1 shows the socio-economic condition of women entrepreneurs. Sonitpur is an agricultural based district. Though number of women entrepreneur is low in comparison to other districts of Assam, entrepreneurship development among women is gradually increasing due to increasing literacy rate, urbanisation, Self Help Groups, multi ethnicity, etc. Table-1 shows that the number of women entrepreneur belonging to 30-40 age groups is highest followed by above 40 years of age group. Field study reveals that highly qualify women were not interested in entrepreneurial activities. They are interested on public and private sector jobs. 42.25 percent women entrepreneurs were $12^{\text {th }}$ standard, 39.30 percent were graduate and 3. 95 percent were M.A. During field study it came to know that number of married women entrepreneur $(50.93 \%)$ was more than unmarried $(35.35 \%)$ women. Number of women belonging to joint family system $(56.05 \%)$ is more than nuclear family $(43.95 \%)$. Because women entrepreneur from joint family can maintain a balance between family and business with help of family members. Widow $(13.72 \%)$ was compelled to join in entrepreneurial activities to cope up financial crisis. Since Sonitpur district is economically backward, monthly income of women entrepreneur is not so high. Majority of respondents $(39.77 \%)$ income falls in the range of Rs. 10,000 to Rs. 30,000. Above Rs, 50,000 is earned only 6.98 percent women entrepreneur. Lack of adequate infrastructure, training facility, insufficient market, etc. is responsible for low income of women entrepreneurs. Due to procedural complicacy, most of the respondents did not take financial help from banks. Their source of income was self. Due to paucity of funds total required investment is not sufficient which hampers the development of entrepreneurship among women in the study area. Moreover, in Sonitpur, there were no medium and large scale women enterprises. All women enterprises are small. Number of registered women entrepreneur was only 34.65 percent and non-registered was 65.35 percent. Due to procedural complicacy in registration, and also the ignorance about the advantages of registration, the number of non-registered women entrepreneur was more than registered. Self created women enterprise is 43.72 percent. Inherited ventures were only 28.37 percent. Women entrepreneur belonging to SC was 33.03 percent which was more than General, OBC and ST (which are 23.73, 19.53, and 23.73 percent respectively). Since economically SC community is very poor, they were compelled to enter into the entrepreneurial activities for survival of their family.

Types of enterprises in which women entrepreneurs were involved in sonitpur district are as follows:

1. Beauty parlour

2. Handloom \& handicrafts (traditional \& nontraditional)

3. Restaurant cum Dhaba

4. Tea stall

5. Grocery / Gift shops

6. Cutting, embroidery and tailoring firms

7. Selling home-made products (like pickle, jeera powder, rice powder, papad, jam- jelly, indigenous snacks (kelti pitha, til pitha.coconut ludduu, tilor luddoo, etc.)

8. Hobby (dance, art, music and yoga) teaching

9. Financial consultancy/insurance agents

10. Crèche

11. Pre-primary school

Number of respondents doing business in different fields (Total respondents 430) Table - 2

Source: Primary data

\begin{tabular}{|l|c|c|}
\hline Sr. no. & Enterprises & Number of respondent \\
\hline 1. & Beauty parlour & 85 \\
\hline 2. & Handloom \& handicrafts(traditional \& non-traditional) & 87 \\
\hline 3. & Restaurant cum Dhaba & 19 \\
\hline 4. & Tea stall & 36 \\
\hline 5. & Cutting and embroidery & 69 \\
\hline 6. & Stationary /gift shop & 35 \\
\hline 7. & Hobby(dance, art, music, yoga)teaching & 16 \\
\hline 8. & Selling home-made items (pickle, papad, jam, jelly, laddu, pie) & 45 \\
\hline 9. & Financial agents & 23 \\
\hline 10. & Creche & 07 \\
\hline 11. & Pre-primary school & 08 \\
\hline
\end{tabular}


Fig - 1

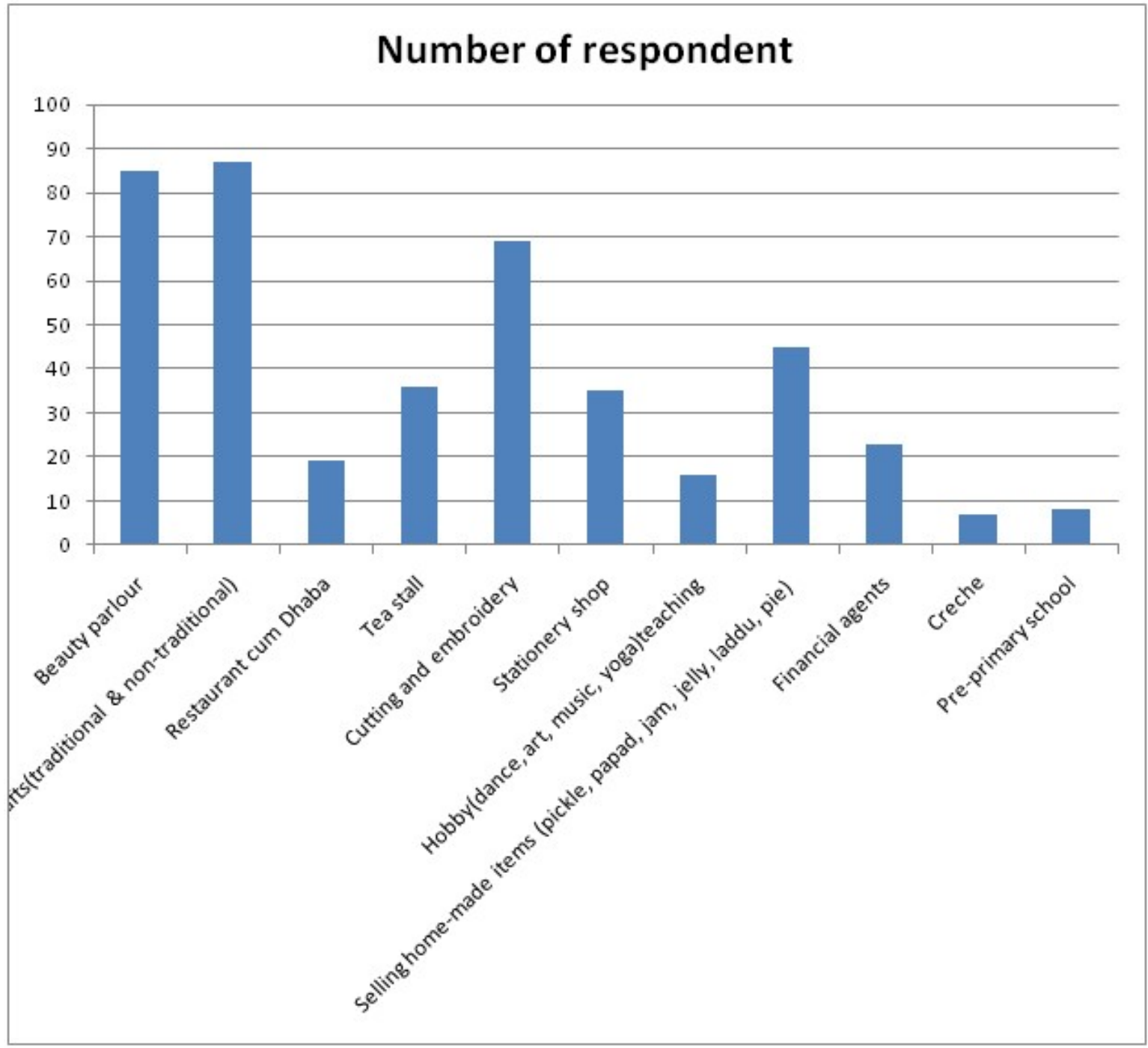

Fig - 1 shows number of women entrepreneurs in different categories. Highest numbers of women entrepreneurs are in handloom \& handicrafts, followed by beauty parlour, and cutting, embroidery and tailoring, selling homemade items, i.e., pickle, jam-jalley, laddu, and different traditional food items, dhaba and tea tall respectively. These types of enterprises can be set up with fewer amounts of money and also at their homes 
International Journal of Trend in Scientific Research and Development (IJTSRD) ISSN: 2456-6470

Infrastructure required for the enterprises mentioned above are as follows:

Table - 3

\begin{tabular}{|c|c|c|}
\hline Sr. No & Enterprises & Infrastructure facilities involved \\
\hline 1. & Beauty parlour & $\begin{array}{l}\text { proper space, power and water supply, Sewage, sanitation } \\
\text { and waste disposal facilities }\end{array}$ \\
\hline 2. & $\begin{array}{lll}\text { Handloom } & \& & \text { handicrafts( } \\
\text { traditional } & \& & \text { non- } \\
\text { traditional) } & & \end{array}$ & Proper space, adequate supply of textiles \\
\hline 3. & Restaurant cum Dhaba & Proper shed, basic utensils, power supply and water supply \\
\hline 4. & Tea stall \& snack & Proper space, water facility and utensils \\
\hline 5. & $\begin{array}{l}\text { Cutting, embroidery and } \\
\text { tailoring firms }\end{array}$ & $\begin{array}{l}\text { Proper space, equipments and necessary machines, power } \\
\text { supply }\end{array}$ \\
\hline 6. & Grocery shop & $\begin{array}{l}\text { Proper space, sanitation and waste disposal facilities, } \\
\text { adequate power }\end{array}$ \\
\hline 7. & Selling home-made items & 'Everything is available' \\
\hline 8. & $\begin{array}{l}\text { Financial } \\
\text { consultancy/agents }\end{array}$ & Proper space, vehicles, computer \\
\hline 9. & $\begin{array}{l}\text { Hobby (dance, music, art } \\
\text { and yoga) classes }\end{array}$ & $\begin{array}{l}\text { Proper space, sanitary facility, convenient place, adequate } \\
\text { power and water supply }\end{array}$ \\
\hline 10. & Crèche & $\begin{array}{l}\text { Well equipped proper space, sanitation and waste disposal } \\
\text { facilities, adequate power and water supply }\end{array}$ \\
\hline 11. & Pre-primary school & $\begin{array}{l}\text { Proper room, a play ground, Toilet facility, water facility } \\
\text { and power supply }\end{array}$ \\
\hline
\end{tabular}

The following table shows the infrastructure facilities available for different categories of entrepreneurs in the study area (Sample size 430)

Table- 4

\begin{tabular}{|c|l|c|c|c|c|}
\hline \multirow{2}{*}{ Sr.no } & \multicolumn{1}{|c|}{ Respondents per Enterprise } & \multicolumn{3}{c|}{ Availability of infrastructure } \\
\cline { 3 - 5 } & \multicolumn{1}{|c|}{$\begin{array}{c}\text { (up-to- } \\
\text { the- } \\
\text { mark) }\end{array}$} & & $\begin{array}{c}\text { (not-up-to- } \\
\text { the mark) }\end{array}$ & \\
\hline 1. & Beauty parlour (85) & 32 & 37.64 & 53 & 62.35 \\
\hline 2. & $\begin{array}{l}\text { Handloom \& handicrafts(traditional \& non- } \\
\text { traditional) (87) }\end{array}$ & 32 & 36.78 & 55 & 63.21 \\
\hline 3. & Restaurant cum Dhaba (19) & 11 & 57.89 & 08 & 42.10 \\
\hline 4. & Tea stall \& snack (36) & 21 & 58.33 & 15 & 41.67 \\
\hline 5. & Cutting, embroidery and tailoring (69) & 25 & 36.23 & 44 & 63.76 \\
\hline 6. & Stationery shop (35) & 15 & 42.85 & 20 & 57.14 \\
\hline 7. & Hobby(dance, art, music and yoga)teaching (16) & 10 & 62.5 & 6 & 37.5 \\
\hline 8. & Selling home-made items (45) & 45 & 100 & 00 & 00 \\
\hline 9. & $\begin{array}{l}\text { Financial consultant (23) e.g. insurance agents, } \\
\text { etc. }\end{array}$ & 17 & 73.91 & 06 & 26.9 \\
\hline 10. & Pre-primary school (07) & 04 & 57.14 & 03 & 43 \\
\hline 11. & Crèche (08) & 75 & 02 & 25 \\
\hline
\end{tabular}

Source: Primary data 
Fig-2

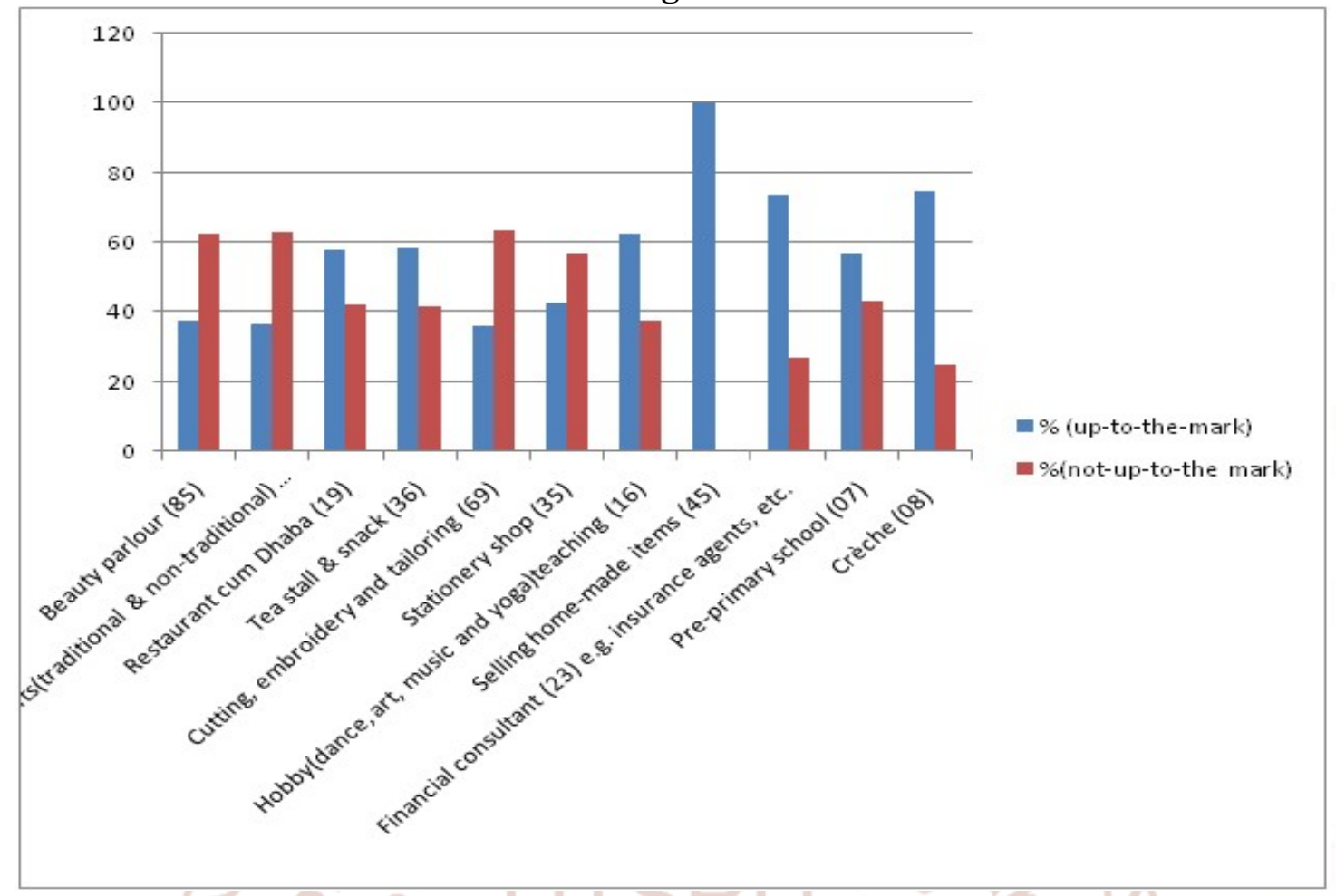

Fig -2 shows the infrastructure facilities available for different categories in percentage basis. Infrastructural facility for beauty parlour, handloom and handicraft, cutting and embroidery, stationary shop, etc. was not up-to-the mark.

At present most popular enterprise for women is found to have a beauty parlour with facilities ranging from spa to basic haircut. Beauticians have to go through a professional course which is easily available in Sonitpur district. During investigation it was found that about $\mathbf{3 7 . 6 4}$ percent beauty parlour is well equipped and $\mathbf{6 2 . 3 5}$ percent is not well equipped. Due to financial crisis and required well furnished room, most of the women entrepreneurs could not provide latest facilities like spa, body massage, etc. moreover, they could not keep products like Oriflame, Avon, Lakme, Lotus, etc. at sufficient amount for selling.

Handloom and handicraft (87) are traditional items which are traded mostly by women entrepreneurs. Handicraft items like printed textiles, embroidered goods, stone curving, pen stands, imitation jewellery, stuffed toys, decorative candles, dry fruits boxes, wood ware, wood design, shawl as art ware, embroidered goods, stone curving, ladies purse, jute items like bags, carpet, etc. are some of the items which fall into the seasonal demand category. Generally they are in demand during festivals. The urban women are doing this type of work throughout the year as it is time consuming and also they are ready with a bulk of stock when in demand. They arrange for exhibitions at different places in trade fairs in order to sell their items of handicraft and handloom like printed textiles, makhela- chadar, sarees, salwar kurta, hanky, handloom bags, and curtain etc. Few women have handloom machines and weavers in their own homes or at different places and the products were in high demand in festivals and marriage seasons. They generally produce traditional items according to the demand of the customers. At present traditional items with modern looks like makhela-chadar and handloom salwar-curta piece, muga shawl, men's kurta, shirt, etc. have highest demand in market. But the problem of entrepreneurs in this sector are high cost of production, paucity of funds, lack of well arranged room, shortage of weavers and power supply. About 63.21 percent of women entrepreneurs in this category have no sufficient infrastructural facility. In India, handicraft and handloom production is a major form of employment next to agriculture and constitutes a significant part of the export effect economy.

Cutting, embroidery and tailoring (69) is very popular and common enterprise run both by the urban and rural entrepreneurs which can be set up with less amount of money. It needs a space especially in the market or nearby market places. Most women 
(63.76percent) who run these types of enterprises do not get a space in convenient place at reasonable rent. Most of the respondents ran their enterprises from their houses. 36.26 percent entrepreneurs have up-tothe mark infrastructural facilities.

Women who run hobby classes $(16 \%)$ where they cater to interests of others and provide guidance for painting, dance, music, art, yoga, etc. Running such hobby classes not only generates income for them but also helps and shows a path to the other women to exploit their talents and work for other big business houses. During investigation it was found that most of the women entrepreneurs (37.5 percent) do not have required infrastructure facilities needed for these woks. Such entrepreneurs do not have own buildings but they take rented rooms in nearby school or room in a convenient place. In case of Yoga class it was found that entrepreneur conducted mostly on open space particularly in community hall or field. At present Yoga class is very popular among people to maintain a good health.

Fig - 3

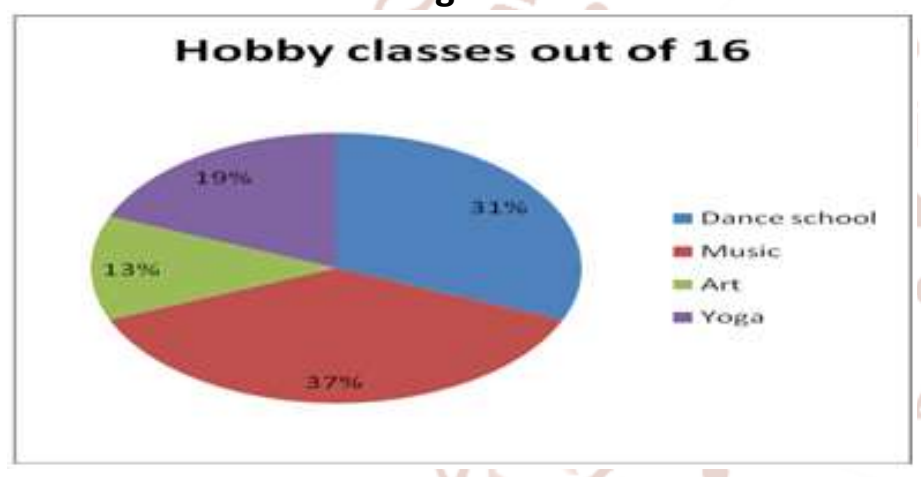

Some women in urban areas with small amount of capital are open crèches $(08)$ which is also known as "Jhula Ghar". This is a place where generally working women belonging to nuclear family can leave their children when out on work. Women entrepreneurs who start this service at home do it for the sake of earning and also utilize their extra space available in their homes. The only expenditure incur here is to arrange for a maid who could assist the small children in toilet training. During field study, it was found that 62.5 percent have well facilities and 37.5 percent have problem of irregular maid servant.

Pre-primary school (07) is the extended form of crèche which can be easily affordable by women who are ready to spend a few thousand in their venture. This type of entrepreneurial activity helps the women to provide basic education to tiny children who are getting ready for their admission in upper class (big school). Women entrepreneur who run that preprimary school generally take Montessori training (which are not much available in Sonitpur district) and can be used to train the children and the junior teachers who assist them in grooming the kids. This type of entrepreneurial activity helps the women to earn and at the same time provide service to the children in the neighbourhood. In the study areas, most of the schools 57 percent are well furnished but they have lack of sufficient playground. About $\mathbf{4 3}$ percent respondent has insufficient facility.

In case of stationary / gift shop (35), trading of stationary and small gift items which the children or adult may require at times also adds to women entrepreneur profit. Although the profit margin is not so much in these gift items but women think that they need to display such items often to attract the customers. 57.14 percent respondents have no up-todate facility to run that type of business activities. They have lack of sufficient stocks of required goods which have high demand. Due to shortage of funds, especially rural women entrepreneur could not run their enterprises properly.

Many women entrepreneurs are found to start a restaurant / road side dhaba. In tea stalls, were also found with a couple of fast moving traditional snacks like til pitha, Ketli pitha, tilor luddoo, coconut laddoo, etc. for quick refreshment at haat bazaar where people from neighbouring villages and the local also visit for the day to day requirement. They earned a sufficient amount on the particular haat bazaar. On the other days they worked either as part time helper in roadside Dhaba or they open their stall in nearby schools / offices. About 42.10 percent entrepreneurs have lack of adequate facility to run restaurant / road side dhaba.

Moreover, modern amenities and lifestyle such curry powder like jeera powder, chilli and turmeric powder, ginger-garlic paste, etc. witness an increasing demand and help most women entrepreneurs to benefit financially. They produce all these items at their homes with available facilities which are not sufficient for commercial purposes. Women entrepreneurs who run enterprises having homemade items assume that everything is available. Therefore this type of women entrepreneurs has required infrastructure facilities. 
International Journal of Trend in Scientific Research and Development (IJTSRD) ISSN: 2456-6470

Awareness of women entrepreneurs about infrastructure facility needed for development of enterprises. Table - 5

\begin{tabular}{|c|l|c|c|}
\hline \multirow{2}{*}{ S.no } & \multicolumn{1}{|c|}{ Respondents per Enterprise } & \multicolumn{2}{|c|}{ Awareness of infrastructure facility } \\
\cline { 3 - 4 } & \multicolumn{1}{|c|}{ (yes) } \\
\hline 1) & Beauty parlour (85) & 65 & 20 \\
\hline 2) & $\begin{array}{l}\text { Handloom \& handicrafts(traditional \& } \\
\text { non-traditional) (87) }\end{array}$ & 62 & 25 \\
\hline 3) & Restaurant cum Dhaba(19) & 17 & 02 \\
\hline 4) & Tea stall \& snack (36) & 28 & 08 \\
\hline 5) & Cutting and embroidery (79) & 79 & 10 \\
\hline 6) & Grocery/Gift shop (35) & 30 & 05 \\
\hline 7) & Hobby(dance, art, yoga, music) teaching & 15 & 03 \\
\hline 8) & Selling home-made items (45) & 25 & 10 \\
\hline 9) & Financial consultancy (23) & 100 & 00 \\
\hline 10) & Crèches(08) & 100 & 00 \\
\hline 11) & Pre-primary school (07) & 100 & 00 \\
\hline 12) & Total & & \\
\hline
\end{tabular}

The above table -5 , shows that the awareness of infrastructure facility available for development of women entrepreneurs in sonitpur district is not satisfactory. The total number of women entrepreneurs is more in urban areas than rural areas and also registered enterprises are more than non-registered in urban areas against the rural areas. Some of the core reasons behind it are illiteracy, lack of sufficient publicity from the government about various schemes and policies related to entrepreneurship development, lack of finance, lack of self confidence, etc. Illiteracy, a significant factor is an important drawback which dominated particularly in rural areas.

Fig -3

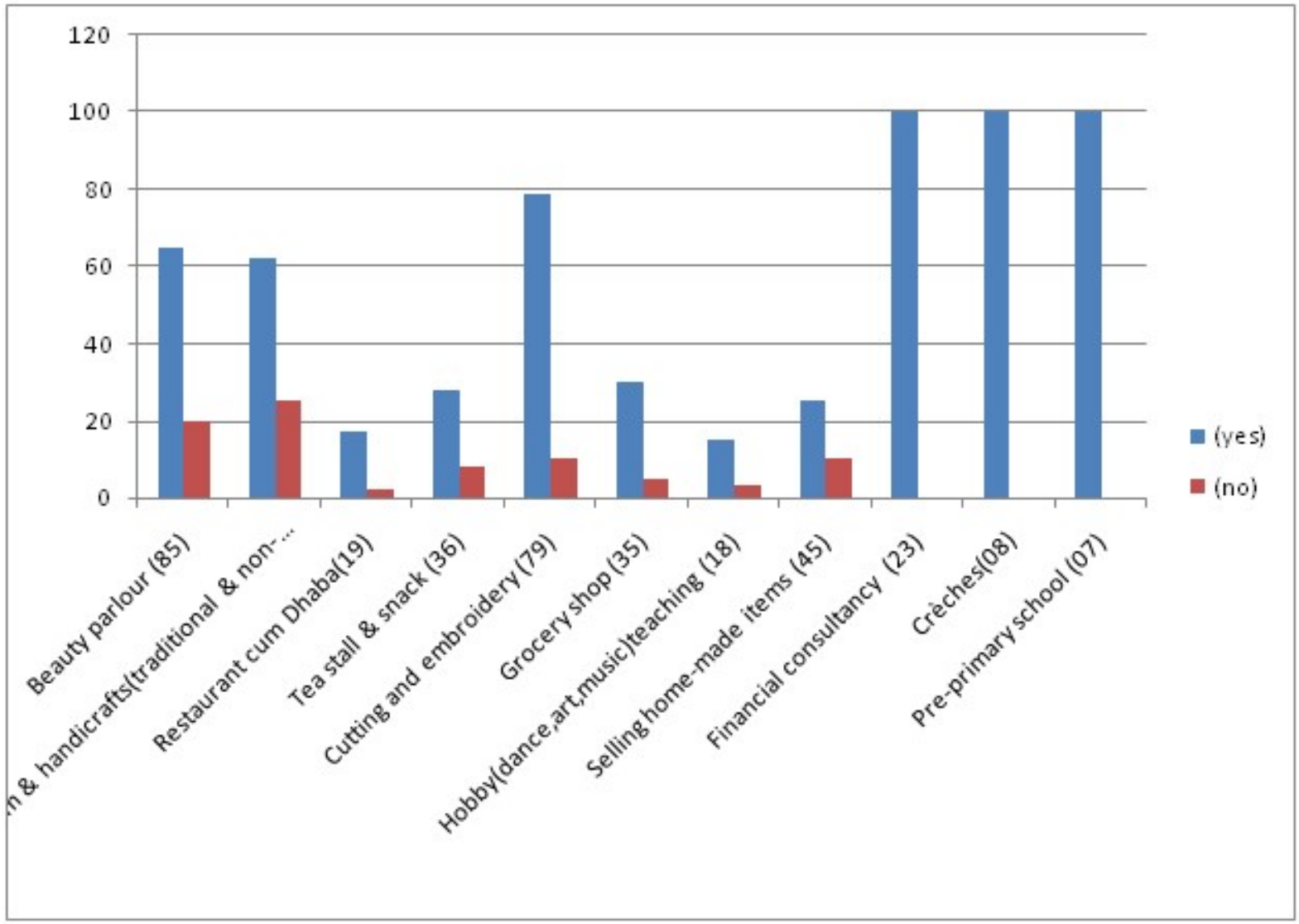

Source: Primary data 


\section{Findings and suggestions:}

1. There is no sufficient infrastructural facility available in the study area. Shortage of power supply, lack of required space, absence of sanitary facility, improper location, lack of waste disposal facilities, equipments and necessary machines, market facility, etc. were observed during field study.

2. Due to ignorance of required facilities needed for starting an enterprise, most of the respondents could not run their ventures successfully.

3. Most of the respondents were untrained and so the quality of their products was not widely acceptable i.e., not according to the taste and preferences of the customer, which reduces the expansion of markets.

4. Large section of women entrepreneur suffers from financial crisis. They did not want to take loan from banks due to procedural complicacy.

5. Due to illiteracy, lack of role model, fear of success, most of the married respondents gave first importance on caring their children and homes and after that they concentrated on entrepreneurial activities with the help of husband or family members.

6. A large section of respondents was unable to take facilities given by government mainly due to lack of awareness and lack of publicity about government policies and programs,

7. During field study, it came to know that in some entrepreneurial activities, the income generation was seasonal. In some season like festival and marriage seasons their (e.g., income of beautician, owner of boutique, handloom and handicrafts, etc.) income generation was satisfactory and in other seasons their income generation was average which was discouraging.

\section{Suggestions:}

1. Government should increase infrastructural facilities like Power supply at concessional rate, financial assistance at low rate of interest, subsidy on equipments and necessary machines, waste disposal facilities, toilet facility and adequate shade for respective businesses to women entrepreneurs.

2. The publicity about government schemes and policies must increase at large extent.

3. The procedure of getting loans from banks must be easy.

4. Training facilities for management of enterprises, income generation, and formulation of the project should increase. Moreover, marketing, financial and technical assistance from DIC, MSME should increase everywhere. Government should arrange exhibition, trade fair at different places from time to time to expand market facilities.

5. Research and development on entrepreneurial activities should be increased.

6. The quality of the products of enterprises run by women must improve and also it should be according to the taste and preferences of the consumers that changes from time to time.

7. Workshop and seminar should be held on both urban and rural areas to increase awareness and interest of women for entrepreneurial activities in new areas.

8. Incentives and subsidy should be given to women to that extent that they would encourage and come forward to start up ventures. Separate industrial estate should be set up especially for women entrepreneurs to reduce starting investment and also to create a conducive environment along with required markets.

9. Since the success of women entrepreneurs depends on the co-operation of family members, availability of skilled and trained workers or labourers, demand of the produced goods, sufficient finance, competition that they faced, etc., therefore government should give emphasis to eliminate all the drawbacks so that entrepreneurship among women would increase in particular and contribute to the national income at large.

\section{Conclusion:}

Entrepreneurship constitutes the driving force of the economy. It is a life blood of an economy. Though infrastructure facilities are not sufficient in Sonitpur district of Assam, yet women entrepreneurs are moving ahead in all spheres. They are not only venturing into traditional business idea but are ready to explore various non-traditional fields and prove their best capacity. During field studies, it was encouraging to observe that against various odds like inadequate business premises, inadequacy of business competencies and lack of skills especially in rural areas, difficulty in maintaining balance between business and family, shortage of power supply, low profit margin, etc. entrepreneurship among women in Sonitpur is moving positively. With the increase of literacy rate among women (60.73, Census 2011), awareness of people, expansion of urban areas, increasing tendency of self employment through 
SHGs (Self Help Groups), etc. women entrepreneurs are moving ahead and have got engage into variety of activities. The appeal of start-up ideas is gradually growing on and so it seems a bright future. In $21^{\text {st }}$ century, the world scenario can be changed by entrepreneurs through their new visions and creative imagination. The laws and regulations related to women employment are insufficient. Despite constitutional provisions, there is discrimination against women. The most important common problems of women entrepreneurs are paucity of adequate finance, lack of proper business knowledge, lack of training, lack of full family support, lack of self-confidence, marketing problems, and lack of awareness among women. Studies have shown that women are less likely to perceive themselves as entrepreneurs and avoid training and courses targeted as 'entrepreneurs'. The impact of family life and child care, as well as a lack of high profile role models are other limiting factors in Indian society. Therefore government should give importance on to provide adequate infrastructural facilities, training and financial assistance to women at large scale so that the trend of women entrepreneur will move positively and expectedly. Empowerment for women in the study areas ultimately helps to building sustainable economies through the development of women entrepreneurship.

\section{References:}

Cohoon, Wadha \& Mitchell,(2010) “ Are Successful Women Entrepreneurs Different from Men ?", ', by Ewing Marion Foundation

Van der M. (2002), A study of discrimination against women entrepreneur when applying for financial assistance. UN published M.Phil thesis, Pretoria: University Pretoria, South Africa.

Carter,S.,(2000), Improving the numbers and performance of women-owned businesses: Some implications for training and advisory services. Education and Training, 42(4/5): 326-334

1. Amy Kothari, President and CEO of Alarm Capital Alliance

2. Christine Wheeler, founder of Drazil Kids Tea.

3. Barwa, S. D., 2003, ILO Vietnam Working Paper Series No. 1, Impact of Start Your Business (SYB) Training on Women Entrepreneurs in Vietnam, ILO Office in Vietnam

4. Christine Wheeler, founder of Drazil Kids Tea.
5. Ghosh, R.N. and Roy, K.C. (1997), "The changing status of women in India: impact of urbanization and development", International Journal of Social Economics, Vol. 24 No.7-9, pp.902-917

6. Goyal, M. \&Parkash, J. (2011), Women Entrepreneurship in India- Problems and Prospects, International Journal of Multidisciplinary Research, Vol.1 Issue 5, pp. 195207.

7. Lee-Gosselin \& J. Grisé (1990), Are women owner-managers challenging our definitions of entrepreneurship? An in-depth survey, Journal of Business Ethics 9 (45):423 - 433.

8. Hookoom Sing and Essoo (2003), SEED Working Paper No. 58, Promoting Female Entrepreneurship in Mauritius: Strategies in Training and Development, International Labour Office, Geneva

9. Jennifer Kent, founder of the Guava Project10. Karim, Nilufer Ahmed (2001), SEED Working Paper No. 14, Jobs, Gender and Small Enterprises in Bangladesh: Factors Affecting Women Entrepreneurs in Small and Cottage Industries in Bangladesh, International Labour Office, Geneva.

10. Kumari, S. (2012), Challenges and Opportunities for Women Entrepreneurship in India under Globalisation, IOSR Journal of Business and Management (IOSR-JBM), ISSN: 2278-487X. Volume 5, Issue 2, pp. 29-35.

11. Kumbhar, A. \&Kumbhar, D. (2011), Problems \& Prospects of Women Entrepreneurs in India, Global Economic Research, Vol. I, Issue: I, ISSN 2249- 4081, pp. 151-159.

12. Kumbhar, V. (2013), Some Critical Issues of Women Entrepreneurship in Rural India, European Academic Research, Vol. I, Issue 2, 185-192.

13. Ruta Aidis, Vice president of research and gender, and GEDI Project director at the Global Entrepreneurship and Development Institute.

14. Mehta, A .\& Mehta, M.C. (2011), Rural Women Entrepreneurship in India: Opportunities and challenges, International Conference on Humanities, Geography and Economics, (ICHGE'22011) Pattaya Dec.2011.

15. Winn, J.(2004), Entrepreneurship not an easy path to top management for women, Women in Management Review, Volume 19, Number 3, pp.143-153 